\title{
Characterising groundwater-dominated lowland catchments: the UK Lowland Catchment Research Programme (LOCAR)
}

\author{
H.S. Wheater ${ }^{1}$, D. Peach ${ }^{2}$ and A. Binley ${ }^{3}$ \\ ${ }^{1}$ Department of Civil and Environmental Engineering, Imperial College London, South Kensington, London SW7 2AZ,UK \\ ${ }^{2}$ British Geological Survey, Maclean Building, Crowmarsh Gifford, Wallingford, Oxon OX10 8BB, UK \\ ${ }^{3}$ Department of Environmental Sciences, Lancaster University, Lancs. LA1 4YQ, UK
}

Email for corresponding author: h.wheater@imperial.ac.uk

\begin{abstract}
This paper reports on a major UK initiative to address deficiencies in understanding the hydro-ecological response of groundwater-dominated lowland catchments. The scope and objectives of this national programme are introduced and focus on one of three sets of research basins the Pang/Lambourn Chalk catchments, tributaries of the river Thames in southern England. The motivation for the research is the need to support integrated management of river systems that have high ecological value and are subject to pressures that include groundwater abstraction for water supply, diffuse pollution, and land use and climate change. An overview of the research programme is provided together with highlights of some current research findings concerning the hydrological functioning of these catchments. Despite the importance of the Chalk as a major UK aquifer, knowledge of the subsurface movement of water and solutes is poor. Solute transport in the dual porosity unsaturated zone depends on fracture/matrix interactions that are difficult to observe; current experimental and modelling research supports the predominance of matrix flow and suggests that slow migration of a time-history of decades of nutrient loading is occurring. Groundwater flows are complex; catchments vary seasonally and are ill-defined and karst features are locally important. Groundwater flow pathways are being investigated using natural and artificial geochemical tracers based on experimental borehole arrays; stream-aquifer interaction research is using a combination of geophysics, borehole array geochemistry and longitudinal profiles of stream flow and solutes. A complex picture of localised subsurface inflows, linked to geological controls and karst features, and significant longitudinal groundwater flow below the river channel is emerging. Management implications are discussed. Strategies to control surface application of nutrients are expected to have little effect on groundwater quality for several decades, and new modelling tools for decision support have been developed to represent these effects. Conventional modelling approaches are limited by the complexities of the subsurface system; catchment areas are difficult to define, hence tracking pollutant pathways to stream receptors is also problematic. Conventional distributed groundwater models have difficulty in capturing key aspects of the groundwater system. This raises important questions concerning the confidence that can be placed in models as routinely used for decision support and the level of knowledge required for catchment management to be placed on a secure scientific foundation
\end{abstract}

Keywords: integrated catchment management, lowland catchment research, Chalk groundwater, surface water-groundwater interactions, unsaturated zone flow and transport

\section{Introduction}

The Water Framework Directive (WFD; CEC, 2000) is being implemented progressively across the European Union and has important implications for river basin management. Its focus on integrated catchment management and, in particular, on ecological quality requires improved understanding of catchment systems and hydro-ecological interactions (Wheater and Peach, 2004). This poses significant scientific challenges. Integrated and multi- disciplinary experiment research is required, which must be based on the associated development of truly interdisciplinary scientific collaboration.

In the UK, the focus of experimental hydrology has been in the uplands, and at small catchment scale $\left(<10 \mathrm{~km}^{2}\right)$. The main facility for multidisciplinary research has been the Plynlimon experimental catchments in Wales. Established in the 1960s, under the scientific leadership of Dr. McCulloch, to resolve uncertainties concerning the 
impact of afforestation on the catchment water balance, they have since provided a focus for hydrological process and upland water quality research (Neal, 1997). However, major management pressures lie in the lowlands, and the catchment management units are significantly larger, of the order of $300-400 \mathrm{~km}^{2}$. Hence, a clear and urgent need was identified for research and research facilities to develop the scientific understanding of lowland catchments to underpin integrated catchment management at these larger scales. Lowland, groundwater-dominated catchments represent a particular set of challenges; management pressures are great, the scientific understanding of the major UK aquifers is poor, and tools for the integrated modelling of surface watergroundwater interactions and associated hydro-ecological processes are limited.

In response to these factors, and in particular in response to the challenge of implementing integrated catchment management under the WFD, the LOwland CAtchment Research programme (LOCAR; Wheater and Peach, 2004) was conceived. UK government funding of $£ 4$ million was obtained for a National Infrastructure for Catchment Hydrology Experiments (NICHE; Wheater and O'Connell, 1998), split equally between LOCAR and CHASM (Catchment Hydrology and Sustainable Management), a sister inititative based on a set of upland catchments (www.ncl.ac.uk/chasm/). In addition, approximately $£ 8$ million was provided by the UK Natural Environmental Research Council for a LOCAR Thematic Research Programme. The aims were to develop new interdisciplinary science and improved modelling tools to meet the challenges of integrated catchment management for lowland permeable catchments, recognising that integrated, multi-disciplinary experimental facilities are essential to support this work.

The conception and implementation of the LOCAR programme is reported by Wheater and Peach (2004). This paper gives an overview of the research programme and highlights some current research findings from one of the sets of LOCAR catchments, the Pang and Lambourn, focusing on new insights into the hydrological functioning of Chalk catchment systems.

\section{The LOCAR experimental catchments}

The main water supply aquifers in the United Kingdom, namely the Cretaceous Chalk and Permo-Triassic Sherwood Sandstone, are situated, for the most part, in lowland England, particularly in the midlands, south and south-east. These aquifers have a major, often dominant influence on the river systems that they underlie. For example, a typical Chalk stream has a predominantly seasonal hydrograph, reflecting the water table dynamics of the aquifer which it drains (winter recharge and a progressive water table decline through summer and autumn); the stormflow component of streamflow response may represent as little as $2 \%$ of the incident rainfall, appearing as noise superimposed on the seasonal hydrograph. The streamflow source migrates seasonally, moving up the catchment in winter and retreating during summer; under drought conditions (or due to overabstraction), flow may cease over significant lengths of channel. Where the geology of a catchment includes poorly permeable superficial deposits, this groundwater-dominated response will be modified by a streamflow regime more characteristic of conventional hydrology, i.e. one in which stormflow response to individual events is a dominant hydrograph component. These permeable lowland catchments are subject to a complex set of management pressures. They are intensely utilised for public and private water supply, are subject to a range of more or less intensive agricultural activities, and commonly support valuable riparian and aquatic ecosystems.

Three sets of catchments were instrumented to create a facility for interdisciplinary research (Peach et al., 2004). It was important that both the major aquifer types were included and that there was a substantive baseline database, including geological information, borehole data, a reasonable historical record of rainfall and flow measurements, water quality data for surface waters and groundwaters and a body of ecological information. Two paired Chalk catchments together with a Triassic Sandstone catchment were selected (Fig. 1).

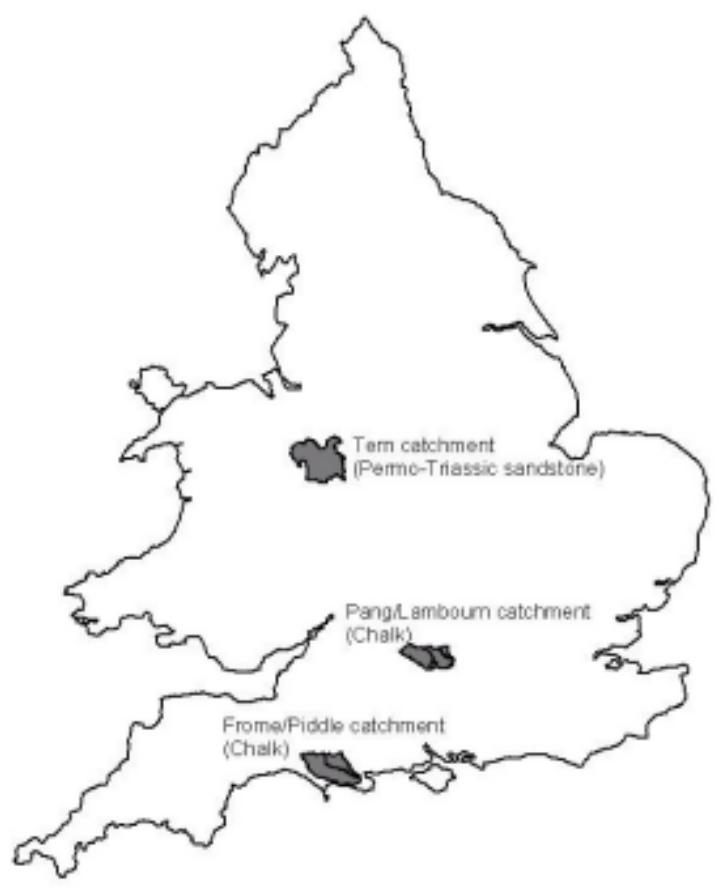

Fig. 1. The LOCAR catchments 
The River Pang, a tributary of the Thames near Reading, to the west of London, was selected to represent the Chalk, because it had been studied over a number of years and several numerical models of groundwater flow had been constructed. Diffuse nitrate pollution was known to be an issue in its management. The adjacent Lambourn catchment was included with the Pang because both catchments overlie the same aquifer system and because the Lambourn includes several wetlands that are candidate Special Areas of Conservation (cSAC) and the whole river length is a Site of Special Scientific Interest (SSSI). A strong historical data set of surface water and groundwater observations existed, together with some historical invertebrate surveys. However, the catchments were lacking any significant background information on fish or sediment transport. These were not, at least at the outset of the research, considered to be major management issues in these catchments.

The River Frome, draining to the south coast of England, was included since it is the only natural salmonid fishery river left in England and had been studied from an ecological perspective over many years by the Centre for Ecology and Hydrology and its predecessors. There was a sufficient baseline of surface water hydrological data, but very little groundwater data. In contrast to the Pang/Lambourn, the catchment is geologically complex, draining not just Chalk but areas of Lower Cretaceous and Palaeogene deposits and recent alluvial sediments. As for the Pang/Lambourn, the adjacent River Piddle was also selected to accompany the Frome because it overlies similar geology and has had major management issues associated with low flow problems. These problems arose because of issues over public groundwater abstractions and, as a result, considerably more groundwater data were available.

The River Tern in Shropshire, a tributary of the river Severn, was included to represent the Permo-Triassic Sandstone permeable catchments. This catchment had a strong historical record of flow, sediment and ecological data and, because of the presence of a major groundwater river augmentation scheme, considerable background groundwater and soil moisture data (the longest set of routine soil moisture measurements in the UK).

\section{The LOCAR research programme}

The broad aims of LOCAR were defined as:

(a) To develop an improved understanding of hydrological, hydrogeological, geomorphological and ecological interactions within permeable catchment systems, and their associated and temporal scales and for different land uses; (b) To develop improved modelling tools to inform and support the integrated management of lowland permeable catchment system.

This was to be achieved through the study of:

- The surface and near-surface environment - surface and near-surface runoff generation, the unsaturated zone, recharge and material transport;

- Groundwater flow and transport processes on lowland permeable catchments, including preferential flows and heterogeneity in flow and transport processes, groundwater/surface water interactions, water/rock interactions;

- Physical, chemical, and biological processes within the valley floor corridor;

- In-stream, riparian, hyporheic and wetland habitats, both structure and function, and their dependence on flow and flux regimes;

- The impacts of society on the functioning of lowland permeable catchments, especially changing land use.

In spring 2002, UK scientists were invited to bid for grant funding, to support projects addressing the LOCAR science objective. The key scientific questions that the academic community was asked to address were:

- What are the key hydrological processes controlling surface water-groundwater interactions, the movement of groundwater and material fluxes in lowland permeable catchments?

- What are the key physical, chemical and biological processes operating within the valley floor corridor that affect the surface water and groundwater?

- How do varying flow regimes control in-stream, riparian and wetland habitats?

- How does land-use management impact on lowland catchment hydrology, including both water quantity and quality, and wetland ecology?

- How can the hydrological, hydrogeological, geomorphological and ecological interactions resulting from natural or anthropogenic changes be predicted using integrated mathematical models?

Research proposals were judged by peer review, based on scientific quality and relevance; Table 1 shows the funded projects. The breadth of interdisciplinary research that is being carried out is unique for the hydrological sciences in the United Kingdom and matches the best of UK community research programmes in the environmental sciences (e.g. the LOIS programme; Leeks and Jarvie, 1998). 
Table 1. List of LOCAR funded projects

\begin{abstract}
Assessment of new methods to estimate grid or catchment evaporation using satellite and ground-based measurements $(\mathrm{P})$

Influence of woodlands on recharge in the Pang catchment $(\mathrm{P})$

Towards a methodology for determining the pattern and magnitude of recharge through drift deposits (T)

Occurrence and fate of agrochemicals in soils and the unsaturated zone (P)

Characterising permeability and groundwater flow in Chalk catchments using tracer techniques (P)

Investigation of groundwater flow heterogeneity in the Chalk aquifer using detailed borehole arrays and stochastic modelling techniques $(\mathrm{P})$;

Contaminant attenuation in Chalk groundwater basins: a new approach using radio-chemistry (P)
\end{abstract}

Assessing stream-groundwater interactions in lowland Chalk catchments using hydrogeophysical characterisation of the riparian zone $(\mathrm{P})$;

Using physical and chemical properties to characterise river/groundwater exchanges in LOCAR catchments (F)

Ecological significance of surface and subsurface exchange in lowland channels (P)

Vegetation management influences on fine sediment and propagule dynamics within groundwater-fed rivers: implications for management, restoration and riparian biodiversity $(\mathrm{T})$

The fine sediment budgets of lowland permeable catchments and their implications for nutrient and contaminant transfer $(\mathbf{F}, \mathrm{P}, \mathrm{T})$

Fine sediments and nutrient dynamics in lowland permeable streams: establishing the significance of biotic processes for sediment modification (F)

Hydrogeochemical functioning in lowland permeable catchments: from process understanding to environmental management (P,F,T)

Utilisation of off-river habitats by lowland river fishes: influences of flow regime and land-use change (F)

\author{
$P=$ Pang/Lambourn \\ $F=$ Frome $/$ Piddle \\ $T=$ Tern catchments \\ bold indicates main focus of effort
}

However, the funding constraints and the limitations of the method of project selection lead to an imbalance in scientific distribution across and between the disciplines and across and between the catchments. The majority of the projects are focused largely on the Pang/Lambourn, including most of those concerned with groundwater flow and transport and groundwater/surface water interaction. Only one project confines its interest to the Tern and that is concerned with recharge processes through glacial drift deposits, which are not present in the other two catchments. Unsaturated zone processes presented a particular research gap, as well as modelling of hydrological processes in the Permo-Triassic and in complex situations like that presented by the Frome/Piddle. However, the LOCAR programme is already attracting complementary research. At least 17 research projects are addressing issues not covered in the main funded programme, including for example, research into unsaturated zone flow and transport processes, impacts of macrophytes on nutrient cycling, and groundwater modelling of the Frome /Piddle.

This research is well under way, and some projects have been completed. After three years there have been important scientific outputs (for the Pang and Lambourn alone, some 30 journal papers are published or in press), but also much progress has been achieved in developing disciplinary integration. The groups of researchers in each of the catchments come together twice a year to discuss progress, with sub-groups meeting more frequently on an ad hoc basis, and an annual science meeting is held for all researchers. This has built a sense of a catchment science research 
community, and as projects have started to deliver results, true scientific integration has begun to emerge. Researchers have found that they can benefit from the experience, advice and knowledge of other disciplines, and in many cases need that shared experience to address their scientific goals and, in particular, to address the broader issues of catchment functioning that underlie management questions and concerns. Representatives of the regulatory and policy community have been represented on the LOCAR Steering Committee and Catchment Management Boards, and have been involved in the steering groups and as active researchers in a number of the research projects. This has been an effective mechanism for two-way communication; researchers (and particularly young researchers) learn of the management concerns, issues and priorities; the environmental regulators and catchment managers gain new insights and improved understanding of the catchment systems, state-of-the-art knowledge, and an improved awareness of the research challenges. Communication of results has also been enhanced by 'stakeholder' meetings within the catchments. The research relies on the support of catchment service teams, responsible for equipment maintenance and the collection of the extensive routine data sets, and also the LOCAR Data Centre, responsible for archiving the routine monitoring data, ancillary data sets of relevance, and the detailed experimental data generated by the individual research projects.

\section{The hydrological functioning of Chalk catchments: insights from the Pang and Lambourn catchments}

\author{
INTRODUCTION TO THE PANG AND LAMBOURN \\ CATCHMENTS
}

Here focus is given to the Pang and Lambourn catchments, in order to summarise some of the insights into the hydrological functioning of Chalk catchments that have been gained to date and hence illustrate the scientific and management challenges associated with such systems. The rivers Pang and Lambourn occupy adjacent catchments in the Berkshire Downs on the north-western margin of the London Basin. The topography and surface water catchments are shown in Fig. 2. The Pang catchment joins the Thames at Pangbourne and lies to the west of the Goring Gap, where the Thames flows through the Berkshire DownsChilterns escarpment. The Lambourn catchment lies immediately to the west of the Pang catchment. The Lambourn is a tributary of the River Kennet and the Pang is a minor tributary of the River Thames.

Annual rainfall varies across the catchment, from a maximum of the order of $743 \mathrm{~mm}$ in the north and west where there are the highest elevations, to a minimum, of the order of $655 \mathrm{~mm}$, in the south and east. The mean annual rainfall (1968-1997) for the Pang is $692 \mathrm{~mm}$ and for the

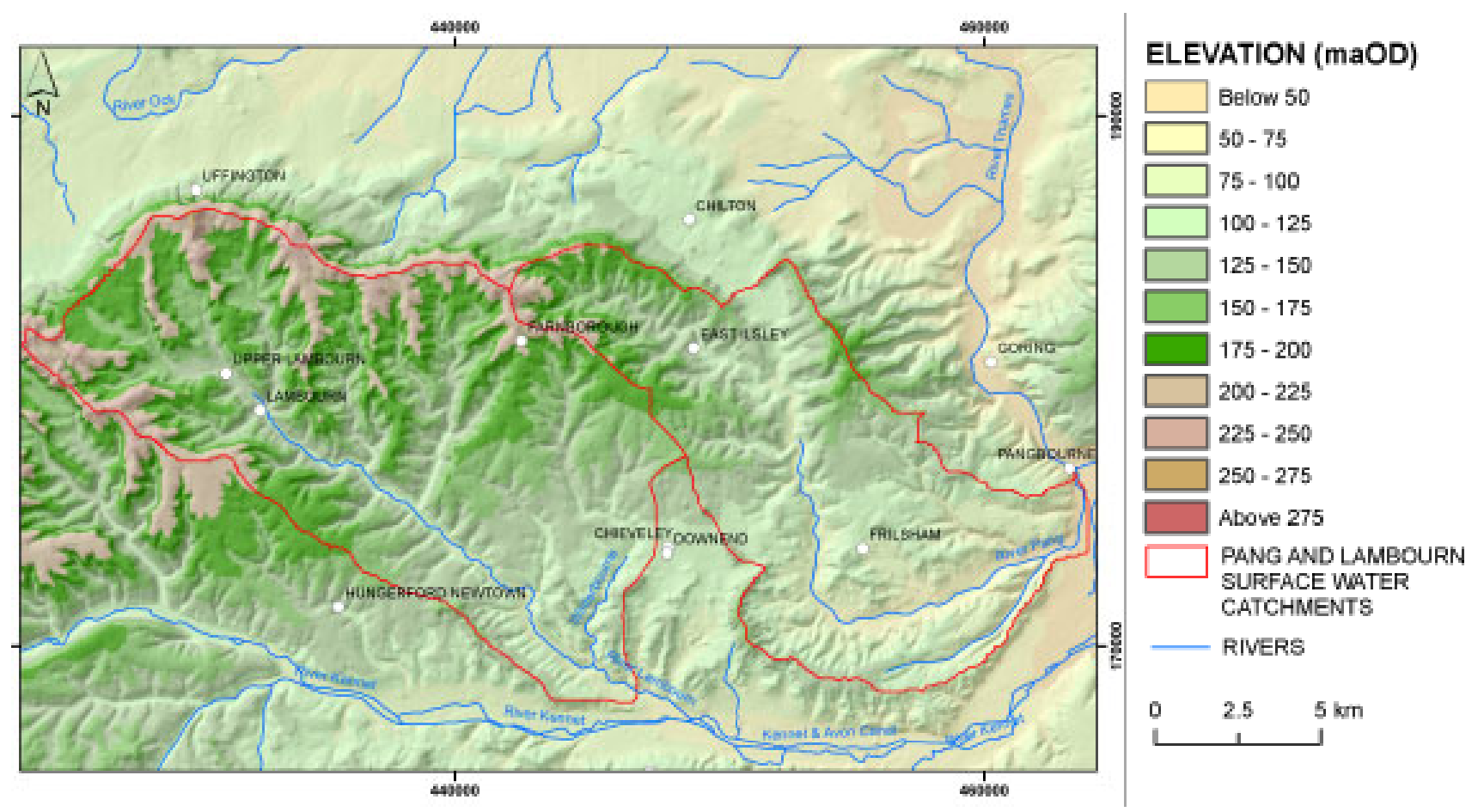

Fig. 2. Pang and Lambourn topography and river system (after Peach et al, 2006) Figure reproduced with permission of the British Geological Survey 
Lambourn is $731 \mathrm{~mm}$ (Peach et al., 2000). LOCAR research has allowed improved estimation of actual evaporation. Preliminary estimates for 2003 range from 300 to $480 \mathrm{~mm}$, as a function of soils, land use and location.

The solid geology is shown in Fig. 3. The catchments lie principally on the Chalk, the main aquifer of the region. The siltstones and sandstones of the underlying Upper Greensand crop out in the north of the area and are themselves underlain by the mudrocks of the Gault and the Kimmeridge Clay. The Chalk is of Upper Cretaceous age, the Upper Greensand and Gault are of Lower Cretaceous age, and the Kimmeridge Clay is of Jurassic age. The area is underlain at depth by Precambrian and Palaeozoic formations, including part of the coal-bearing Berkshire Carboniferous depositional basin. In the south of the area, the Chalk is overlain by deposits of Palaeogene age, consisting of the Lambeth Group, the silty clay of the London Clay Formation and the sands of the Bagshot Formation. Superficial deposits of Quaternary age comprise Clay-with-flints, some of which is sandy, Head deposits in a variety of topographic situations, Holocene alluvium, and peat and River Terrace Deposits. Table 2 summarises the post-Triassic stratigraphy of the area.
Both catchments are thus predominantly underlain by the Chalk. The north-facing Chalk scarp slope of the Berkshire Downs defines the northern boundaries of the catchments. The rivers drain in a generally south-easterly direction down the dip slope of the Chalk Downs towards the River Kennet and the River Thames. Both rivers are fed by the Chalk aquifer and exhibit many of the characteristics of Chalk groundwater-dominated river systems. The dominant influence on regional groundwater flow is the River Thames and, to a lesser extent, the River Kennet. However, locally, groundwater flow may be influenced by structures in the Chalk, and by sub-karstic development and near surface weathering of the aquifer.

The infrastructure installed for LOCAR on the Pang and Lambourn catchments builds on existing flow and groundwater monitoring sites (Fig. 4). These include rainfall and climate stations, the direct measurement of evaporation using eddy-flux correlation techniques, intensive instrumentation of the unsaturated zone using complementary methods for both moisture content and pressure potential at seven recharge sites, a monitoring network of groundwater piezometers and experimental groundwater

Table 2. Post Triassic stratigraphy of the area

\begin{tabular}{|c|c|c|c|c|c|}
\hline PERIOD & & & & SUPERFICIAL DEPOSITS & \\
\hline \multirow{6}{*}{ 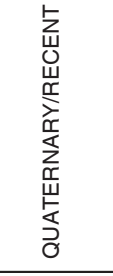 } & & & & & \\
\hline & & & & Head & \\
\hline & & & & Clay-with-flints & \\
\hline & & & & Peat & \\
\hline & & & & Alluvium & \\
\hline & & & & River Terrace Deposits & \\
\hline & & & & \multirow{3}{*}{ SOLID GEOLOGY } & \multirow{3}{*}{$\begin{array}{l}\text { Traditional } \\
\text { subdivisions } \\
\text { of the Chalk }\end{array}$} \\
\hline & EPOCH & STAGE & \begin{tabular}{|l} 
CHALK \\
SUBGROUP
\end{tabular} & & \\
\hline \multirow{4}{*}{ 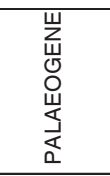 } & & & & & \\
\hline & \multirow{2}{*}{ Eocene } & & & Bagshot Formation & \multirow{4}{*}{ Upper Chalk } \\
\hline & & & & London Clay Formation & \\
\hline & \multirow[t]{2}{*}{ Palaeocene } & & & Lambeth Group & \\
\hline \multirow{10}{*}{ 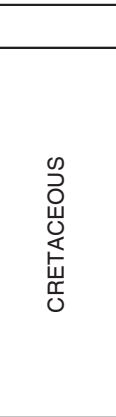 } & & & & unconformity & \\
\hline & \multirow{7}{*}{ 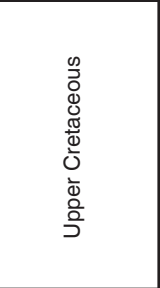 } & \multirow{7}{*}{ 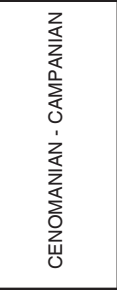 } & \multirow{5}{*}{ 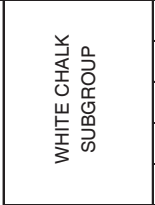 } & Newhaven Chalk Formation & \multirow{3}{*}{ Upper Chalk } \\
\hline & & & & Seaford Chalk Formation & \\
\hline & & & & Lewes Nodular Chalk Formation & \\
\hline & & & & New Pit Chalk Formation & \multirow{2}{*}{ Middle Chalk } \\
\hline & & & & Holywell Nodular Chalk Formation & \\
\hline & & & \multirow{2}{*}{$\begin{array}{l}\text { GREY CHALK } \\
\text { SUBGROUP }\end{array}$} & Zig Zag Chalk Formation & \multirow{2}{*}{ Lower Chalk } \\
\hline & & & & West Melbury Marly Chalk Formation & \\
\hline & \multirow{2}{*}{$\begin{array}{c}\text { Lower } \\
\text { Cretaceous }\end{array}$} & \multirow{2}{*}{ ALBIAN } & & Upper Greensand Formation & \\
\hline & & & & Gault Formation & \\
\hline \multicolumn{4}{|l|}{ 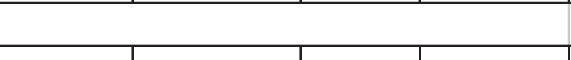 } & unconformity & \\
\hline JURASSIC & Upper Jurassic & & & Kimmeridge Clay Formation & \\
\hline
\end{tabular}



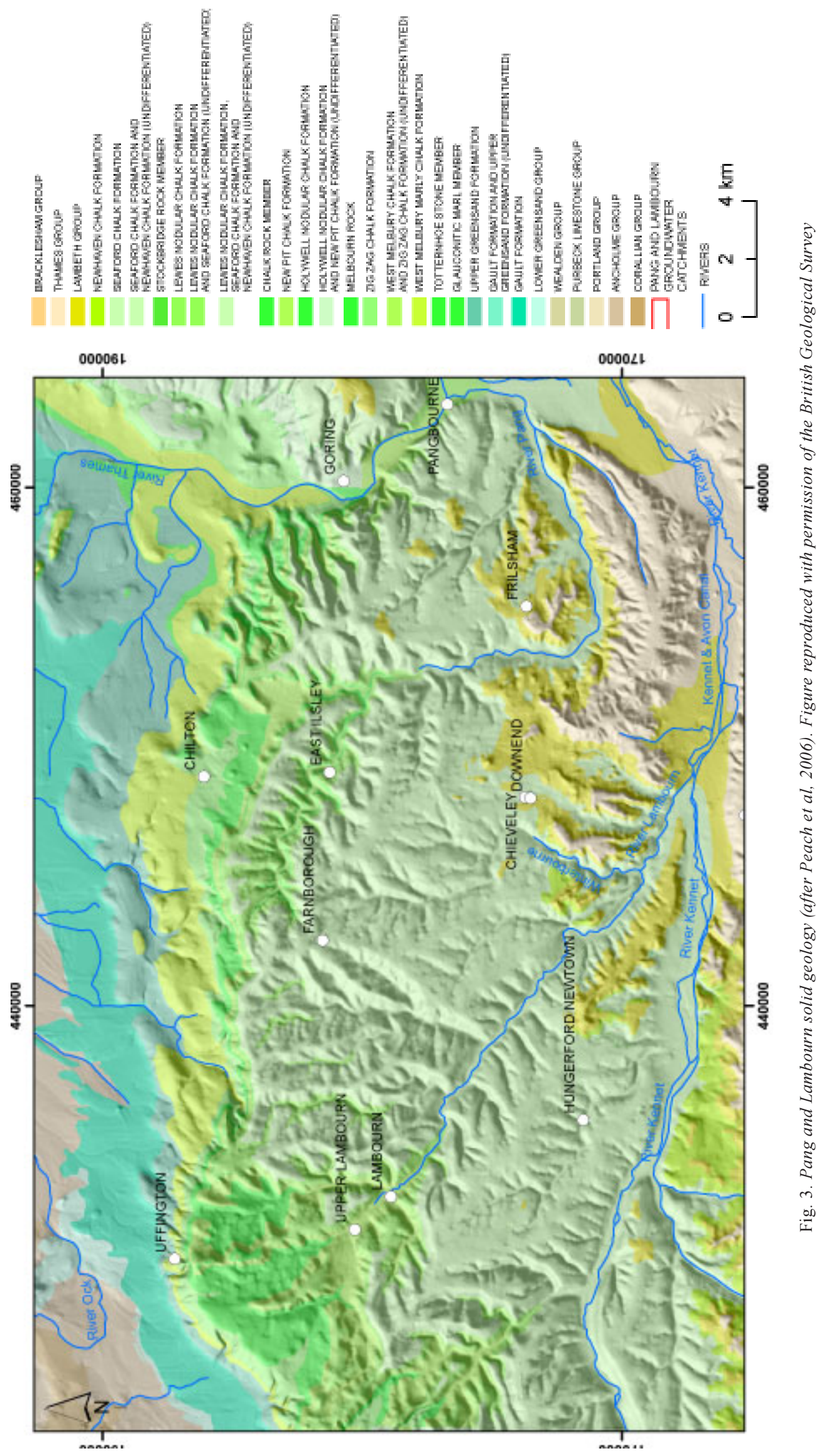


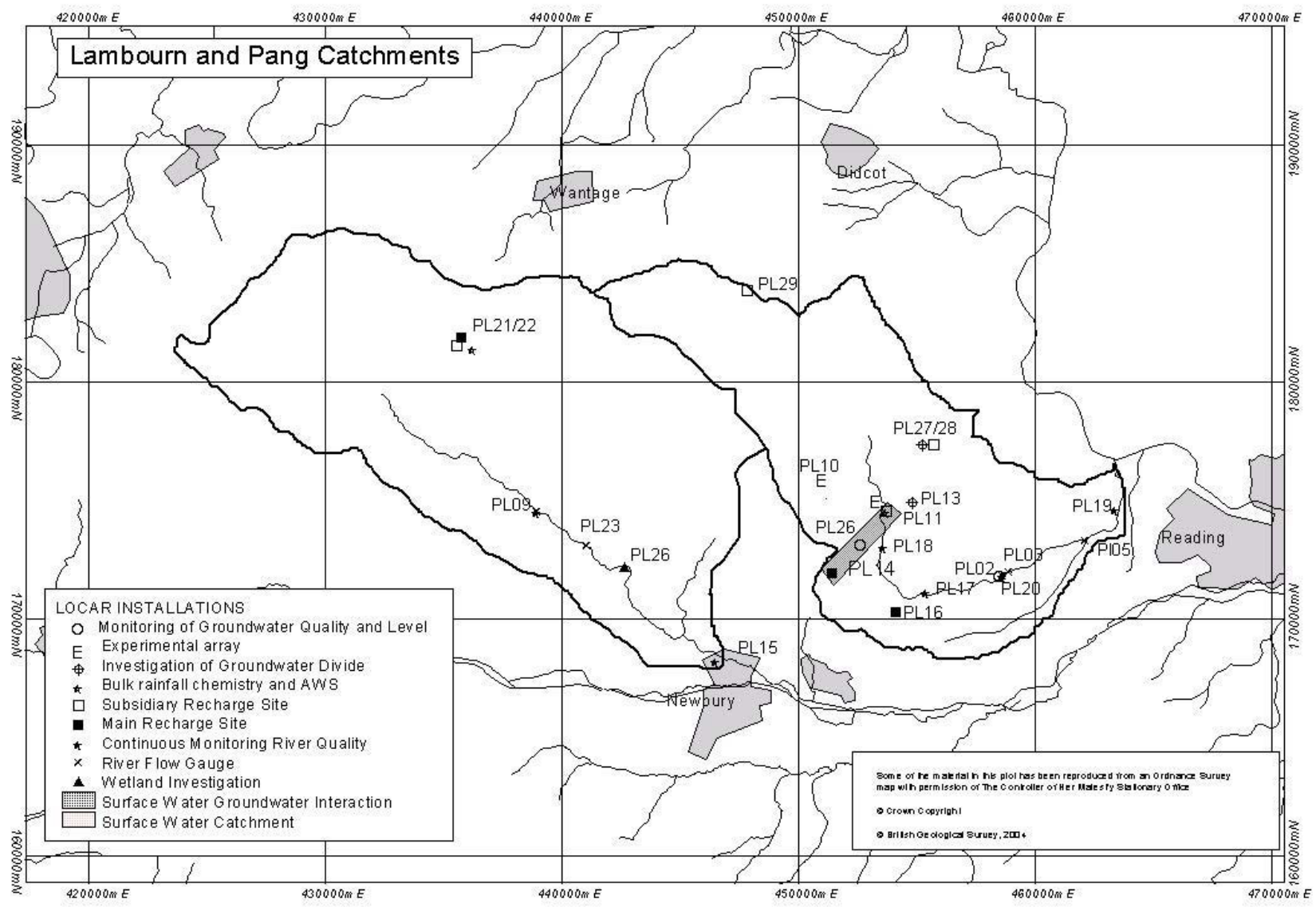

Fig. 4. LOCAR instrumentation, Pang and Lambourn catchments (after Adams et al, 2003)

Figure reproduced with permission of the British Geological Survey

arrays, and stream discharge and water quality measurements, including continuous monitoring of suspended sediments. Individual research projects have built on this infrastructure with more specialist investigation of specific sites.

\section{CHARACTERISTICS OF THE CHALK}

The Chalk is a fine-grained, pure $\left(c .98 \% \mathrm{CaCO}_{3}\right)$, soft, white limestone containing thin marl beds and flints. Typical matrix pores have pore throats of the order of $1 \mu \mathrm{m}$ in diameter, or less. Larger voids are defined by the fracture porosity. Fracture apertures range from a few microns to about $1 \mathrm{~mm}$ for primary, or undeveloped, fractures, and up to a few tens of centimetres for secondary fractures where there has been local karstic development of the fracture. Matrix porosity typically ranges from about $45 \%$ to $20 \%$. Marls and beds with higher clay contents generally have lower porosity and porosity generally reduces with depth. The marl beds are layers sub-parallel to bedding, typically a few millimetres but occasionally up to a few centimetres thick, which contain higher concentrations of clay minerals.
Some marl beds are likely to be laterally continuous across the catchments. Flints occur predominantly in layers parallel to bedding although they may fill sub-vertical fractures. Flints may be nodular (irregular or lumpy in appearance) or tabular (flat and sheet-like). Like some marls, some flints are laterally continuous across the catchments. Both the larger marls and flint beds may act as a focus for flow in the saturated zone and may cause perched water tables to develop in the unsaturated zone. Also within the Chalk, beds known as 'hardgrounds' occur. These may have porosities as low as $5 \%$, are continuous throughout the Chalk and are used as marker horizons. Like marls and flints, hardgrounds may also be important groundwater flow horizons.

The Chalk is pervasively fractured, with fracture density and fracture characteristics varying spatially and with depth. The fractures are essentially well connected. Due to the small pore-throat size of the matrix, the matrix hydraulic conductivity of the Chalk matrix is small and groundwater flow takes place principally through the fracture network. Price (1987) and Price et al. (1993) identified two components of the fracture network in the Chalk, i.e. primary fractures (principally tectonic in origin) and secondary 
fractures, which are primary fractures modified by processes associated with groundwater flow, with generally preferentially enlarged apertures. Price (1987) and Price et al. (1993) suggested that groundwater flow and transport in the Chalk is primarily through the secondary component of the fracture network.

Fracture style and intensity have been reported to correlate with lithostratigraphy and with syn-sedimentary structures in the Chalk of the South Downs (Mortimore, 1993; Jones and Robins, 1999). For example, Jones and Robins (1999) noted that in the South Downs the Seaford Chalk exhibited medium-spaced regular joints while the underlying Lewes Nodular Chalk fracturing was in the form of more widely spaced conjugate joints. Correlations between fracturing style and stratigraphy have yet to be established for the Chalk of the Berkshire Downs. Although it is likely that synsedimentary structures such as the synclinal structure near Boxford may locally influence fracturing style and density, the dominant trends are as a function of depth and position in the catchments. The highest density of fracturing is usually found near the land surface and in valleys and dry valleys and the lowest fracture densities are found in the interfluve areas and at depth. Generally, fracture density varies as a function of location in the catchment and with depth while fracture apertures vary depending on the hydrogeological setting and history. Fracture density decreases approximately log-linearly with depth below ground level. Figure 5 (after

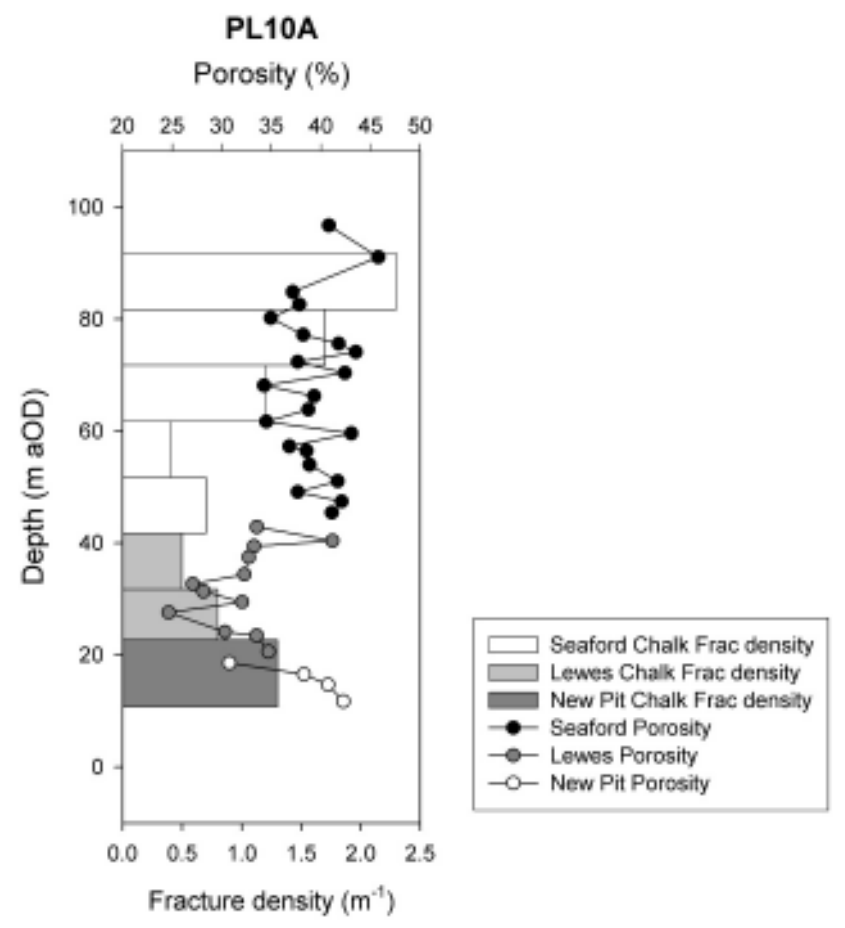

Fig. 5. Typical profile of Chalk fracture density (after Peach et al, 2006). Figure reproduced with permission of the British Geological Survey
Wheater et al., 2006) is a plot of variations in fracture density with depth below Trumpletts Farm, P (site PL10) annotated to show the probable range of fracture density profiles across the catchments.

These complex characteristics of the Chalk influence the surface response to precipitation, the movement of water and solutes through the thick unsaturated zones, groundwater flow and transport and the interactions between the aquifer and the stream.

Groundwater flows in the Pang and Lambourn catchments. Despite the importance of the Chalk as a major UK aquifer, knowledge of the subsurface movement of water and solutes is poor. Groundwater flows are complex; catchments vary seasonally and are ill-defined and karst features are locally important. As noted above (see Fig. 3), the Lambourn is predominantly a Chalk system; the Pang by contrast, has extensive areas of Palaeogene deposits in the lower reaches. The stream hydrographs (Fig. 6a) clearly reflect this. The Lambourn flows are dominated by a seasonal response, reflecting groundwater recharge during the late autumn and winter and the subsequent drainage of groundwater to the streams. Response to individual storm events is limited, and appears as a high frequency perturbation on the seasonal groundwater-dominated flows. The Pang shows the same underlying seasonal response, but with a much more significant stormflow response to individual events. The baseflow stream chemistry is represented in the Piper diagram of Fig. 6b, together with the chemistry of waters sampled from springs located on the Paleaogene. A simple picture emerges. Predominantly bicarbonate Chalk water dominates the Lambourn stream chemistry, whereas the Pang waters lie on a line defined by the mixing of the Chalk and the Paleogene sources. Neal et al. (2004a, b) has studied the full range of dynamic response of the hydrochemistry of the streams in detail. Background concentrations tend to increase with flow, whereas point source inputs (predominantly nutrient discharges from sewage treatment works) dilute as streamflow increases. Trace metals demonstrate few patterns, but $\mathrm{Ca}, \mathrm{Sr}, \mathrm{Ba}$ and $\mathrm{Mg}$ show systematic effects. It is hypothesised that inputs to the stream from septic tanks may also show a flushing effect.

Figure 7 illustrates the seasonal variation of groundwater elevations. Data from autumn 2002 (seasonally low values) and spring 2003 (seasonally high values) (see also Fig. 6a) show several significant features. The convergence of groundwater head contours shows that the Lambourn river is clearly a sink for the groundwater; in contrast, groundwater flows east south-east under the river Pang, towards the river Thames, which provides an important boundary for the groundwater system. The apparent 


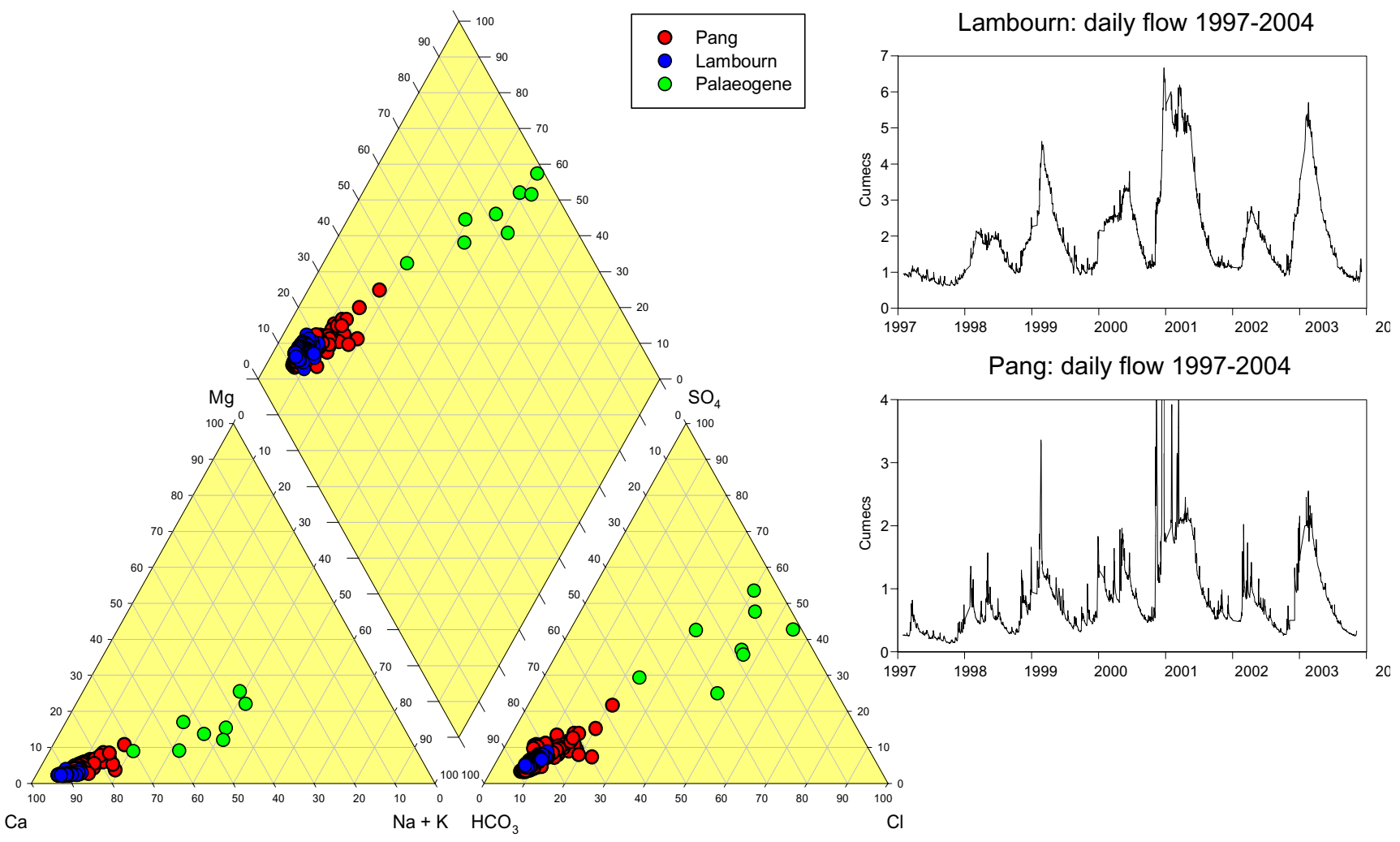

Fig. 6. Stream hydrographs and baseflow chemistry (after Wheater et al., 2006)

Figure reproduced with permission of the British Geological Survey

groundwater catchment area varies seasonally, and is quite different from the topographic catchment (Fig. 2). The effect of this is also apparent from stream flow records: discharge per unit area of topographic catchment at the outflow of the Pang at Pangbourne is typically $50 \%$ of that observed at the Lambourn outflow at Shaw.

Flow accretion profiles are illustrated for the Lambourn in Fig. 8a and for the Pang in Fig. 8b. The accretion profiles show both gaining and losing reaches, and Fig. $8 \mathrm{~b}$ illustrates the seasonal migration of the source of the flowing river which gives these Chalk streams their characteristic 'bourne' behaviour. The Pang data also illustrate a particularly important inflow, located downstream of Jewell's Farm. This is a spring, the 'Blue Pool', which provides significant flows throughout the year, of particular importance during low flow periods, when it can account for more than half of the river flow.

Some of the inflows to the stream arise at the junction of dry valleys, which are another characteristic feature of the Chalk landscape, and often appear to be fault-controlled. Karst features, including the extensive occurrence of swallow holes, are found, particularly in areas of, or adjacent to, Palaeogene cover (Fig. 8). The Blue Pool is associated with karstification, and shows a duality of response. Its ability to support major flows throughout the year demonstrates a large storage and slow response. On the other hand, historical tracer testing (Banks et al., 1995), confirmed by recent work of Maurice (Maurice et al., in press) has demonstrated travel times of the order of several kilometres per day. While tracer tests provide confirmation of certain flow connections, the contributing area of the Blue Pool has not been fully defined. However, it is probably fed from an area immediately to the west and to the south of the spring, by a system of stream sinks at the Palaeogene/Chalk boundary and by leakage from the Palaeogene.

The groundwater flow regime can be summarised as follows:

- Groundwater flow in the Berkshire Downs is dominated by the Rivers Kennet and Thames.

- Groundwater flows to the Lambourn from the high in the north and down dry valleys that run perpendicular to the river.

- Between the Pang and Lambourn some groundwater sheds to the Kennet.

- The Pang groundwater catchment is almost impossible to define, except in the lower reaches.

- The Pang is best conceptualised as a high level ephemeral drain, under which for much of the year groundwater flows towards the Thames. 


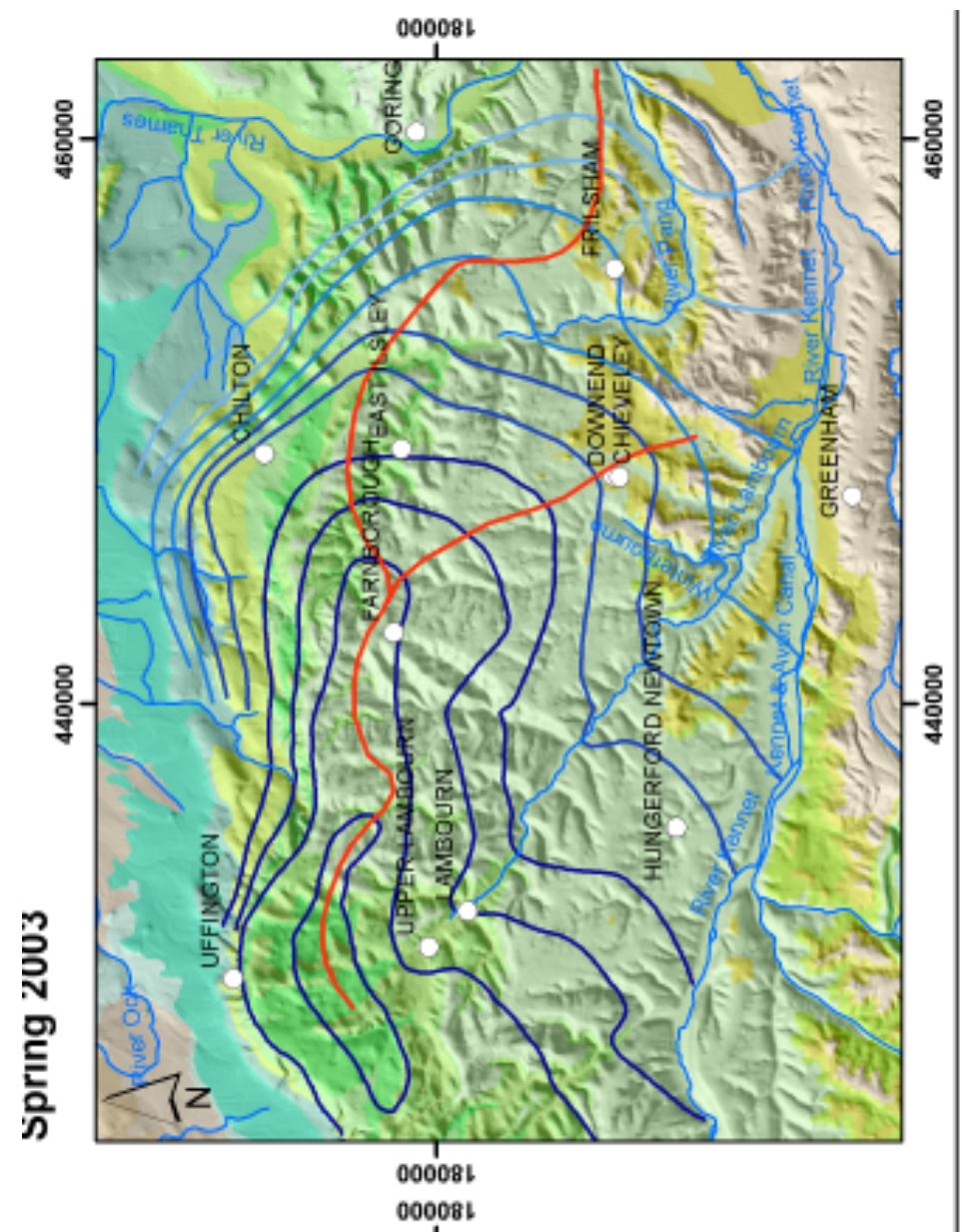

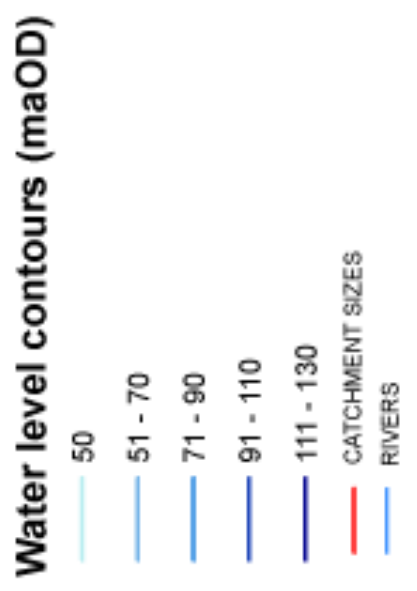

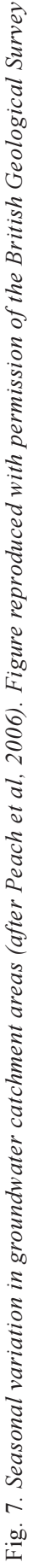

a
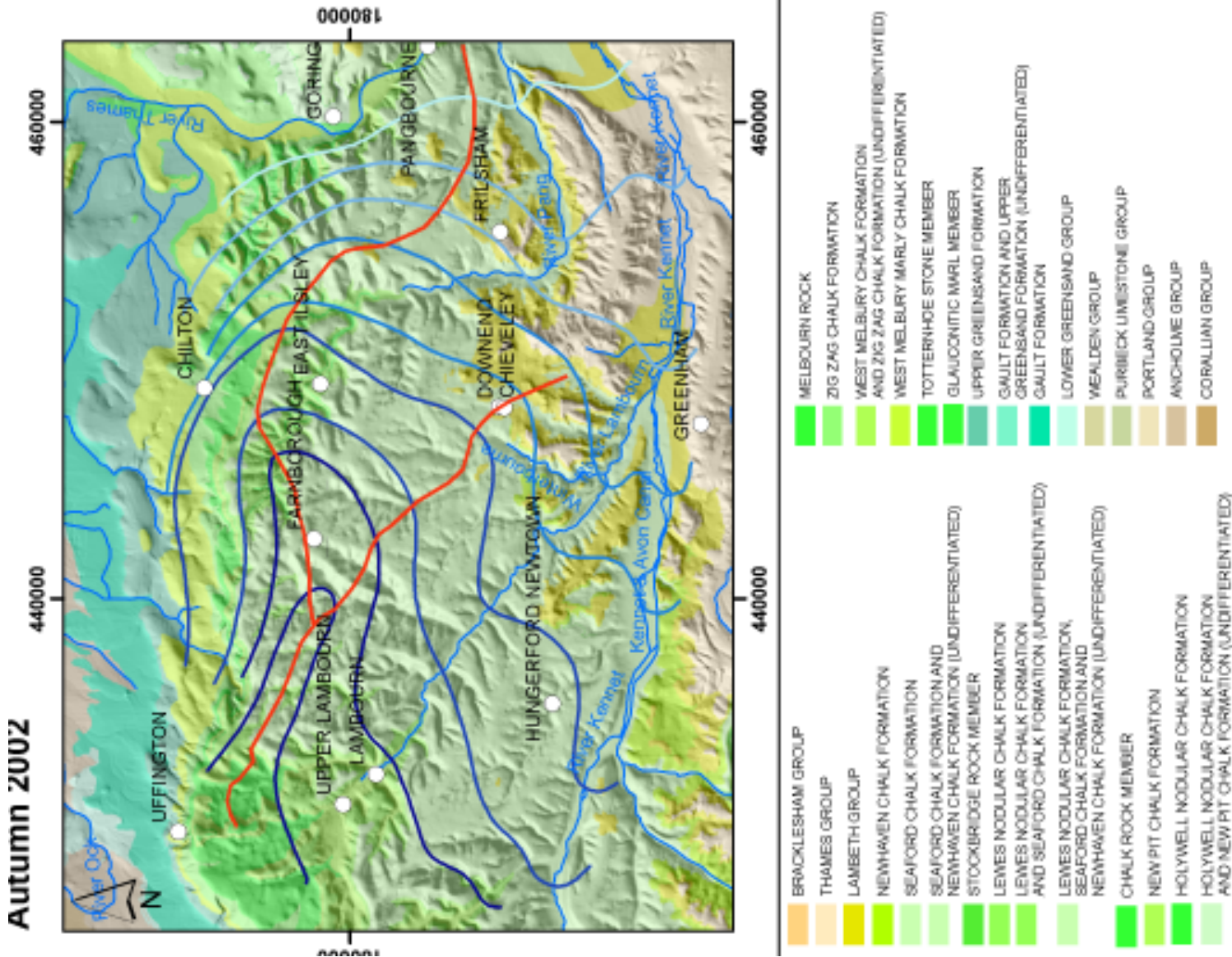

灰

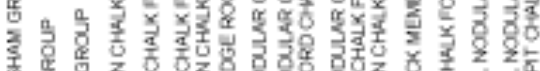

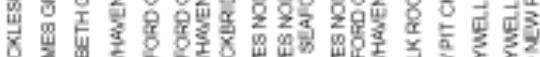

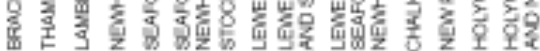




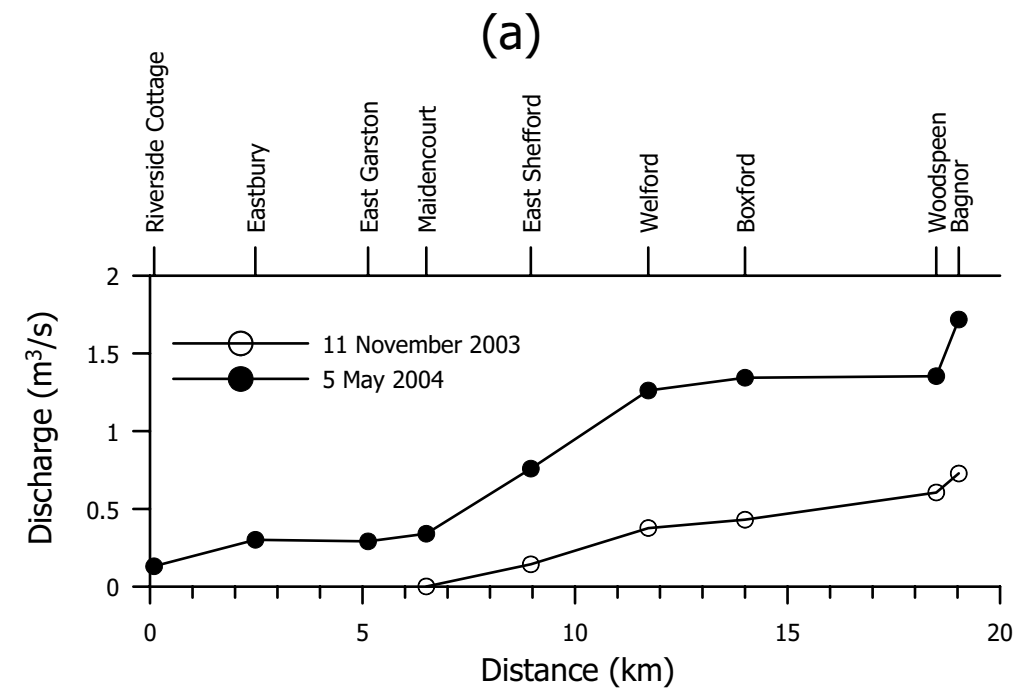

(b)

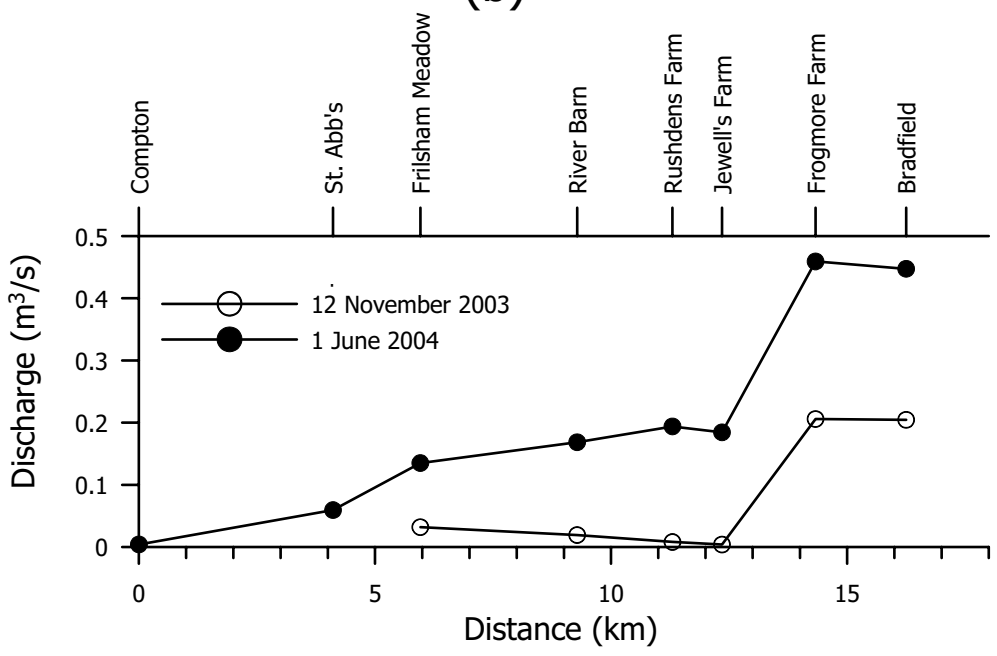

Fig. 8. Flow accretion profiles (a) River Lambourn, (b) River Pang

- In periods of very high rainfall (e.g. winter 2000), flows occur in the upper Pang.

- Up to half of all flow in the Pang at Pangbourne originates from the Blue Pool. This is a karst-dominated spring.

- The flow from the Blue Pool is sustained at a relatively high level throughout the summer, probably from storage in the Palaeogene sediments.

- Both rivers have significant valley flood plains, which will undoubtedly transmit water downstream, beneath the river bed. Horizontal permeability will be far greater, on average, than vertical permeability.

\section{Stream-aquifer interactions}

The results of Fig. 8 illustrate the complexity of stream- aquifer interactions. Some gaining sections are associated with inflows from dry valleys and some from karstic springs, such as the Blue Pool. The experimental borehole array located at Westbrook Farm, near Boxford, on the river Lambourn (PL26, Fig. 4) illustrates some of the local detail. This borehole array includes one transect from the interfluve to the river, as shown in Fig. 9, and a perpendicular transect adjacent to the river with multiple depth installations. The groundwater head measurements for the Chalk piezometers at the Westbrook Farm site indicate a hydraulic gradient towards the river, although this is small $\left(c .4 .2 \mathrm{~m} \mathrm{~km}^{-1}\right)$. Close to the river, where gravels overlie the Chalk, the heads in the gravels were lower than the Chalk, indicating an upward head gradient with potential for the gravels to be recharged from the underlying Chalk. The estimated level of the river 
Lambourn was higher than the gravels but less than the Chalk, implying a potential for the gravels to be recharged from the river. The differences in head measurements between the river and gravels show that there is poor connectivity at the site. The small peaks on the river and groundwater hydrographs, which occur around two days after rainfall events, indicate a relatively rapid response on short timescales, superimposed on long-term seasonal variations. The peaks are followed by a clear recession curve and might be explained by by-pass flow. Much of the Chalk beneath the gravels is heavily weathered, often containing remnant clasts of fresh chalk with dissolution features at their edge. The presence of brown staining in the surrounding weathered chalk, due to oxidised iron, is consistent with the oxidising nature of groundwater. These beds of putty chalk and fractured and 'destructured chalk' were common in the core from borehole 26G. The differences in head between the different units indicate the potential direction of flow but not whether it is occurring or not.

In contrast to these observations at Boxford, measurements of flow and groundwater heads in the upper Lambourn, at an additional experimental site at East
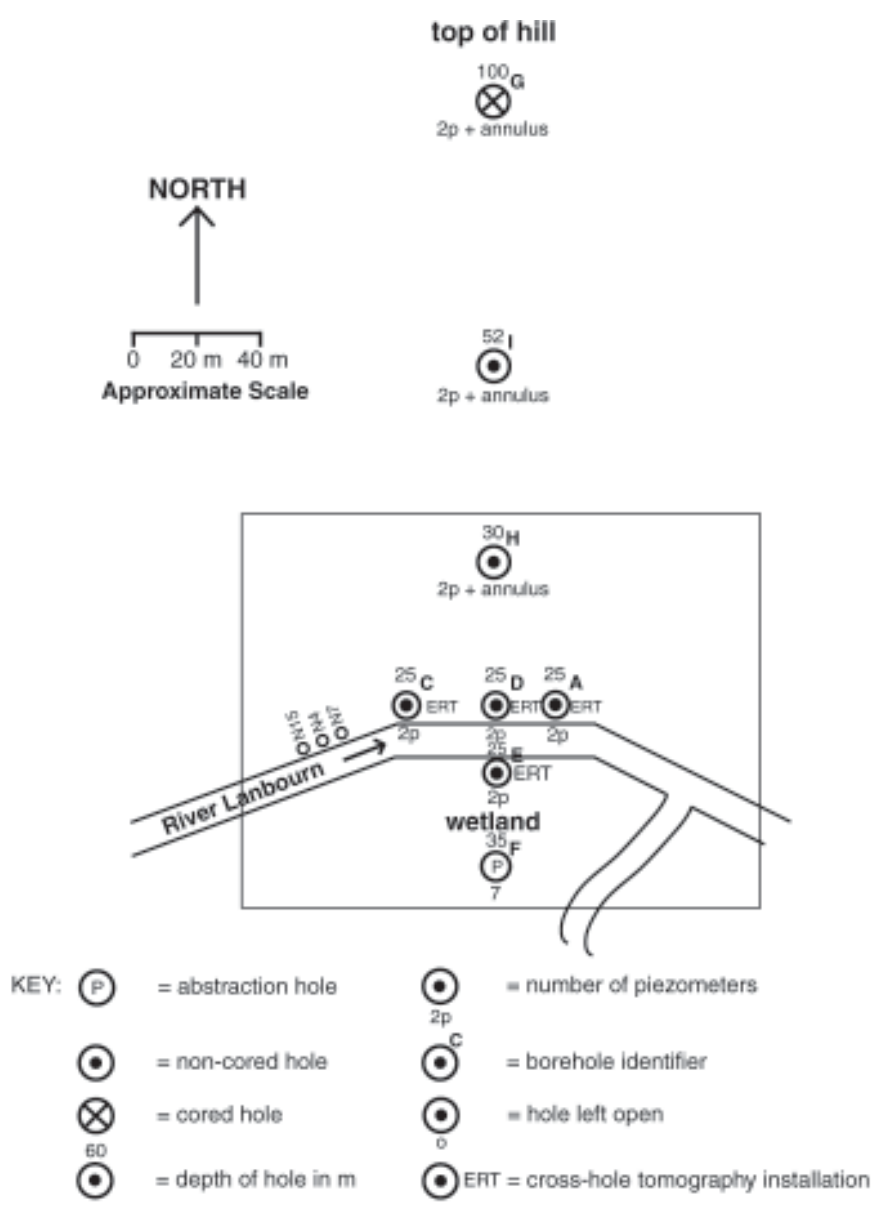

Shefford, reveal a significant positive correlation between the hydraulic gradients across the Chalk/gravel interface and flow accretion in the river. Clearly, the interactions between the Chalk and the overlying alluvium are spatially heterogeneous, as are the interactions between the stream and the alluvium, and the results are consistent with the hypothesis that the valley alluvium provides a significant subsurface flow system underneath the flowing channel.

\section{Unsaturated zone flow and transport}

Flow and transport processes in the unsaturated zone are scientifically important and have great significance for catchment management, since they determine groundwater recharge and the migration of diffuse pollution from the surface to the water table. Unsaturated zones can be thick (up to $120 \mathrm{~m}$ on the Pang and Lambourn; Fig. 10) and both flow and solute transport in this dual porosity zone depend on fracture/matrix interactions that are difficult to observe. There is a duality of observed response; water table rise from winter effective rainfall is observed within days (e.g. Headworth, 1972), whereas solute profiles, for example of nitrate and tritium, have been observed to move down the

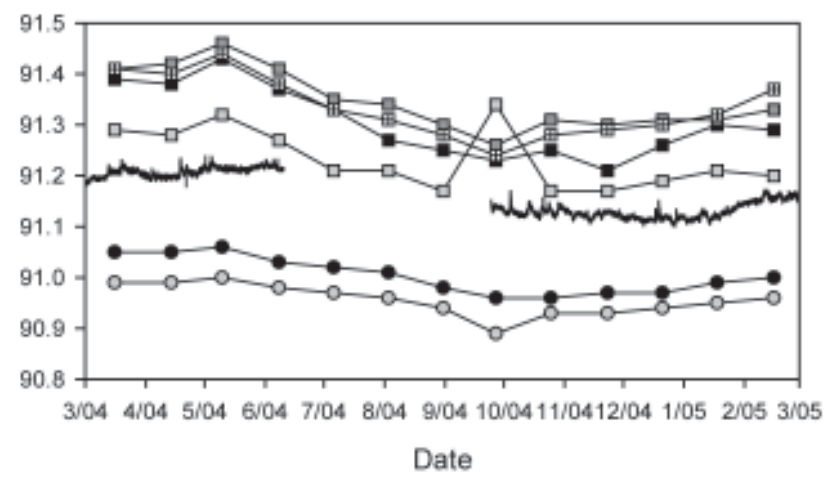

Fig. 9. Groundwater levels at Westbrook Farm, River Lambourn (after Peach et al, 2006) 
profile, with little dispersion, at a rate of less than $1 \mathrm{~m} \mathrm{yr}^{-1}$ (Oakes, 1977). As discussed by Mathias et al. (in press), the history of Chalk unsaturated zone transport modelling has reflected alternative interpretations of the underlying physical processes. Early modelling of solute transport (e.g. Oakes et al., 1981), based on steady-state flow, assumed that flow occurred in the fractures but that solutes diffused instantaneously into the matrix. Subsequent work (e.g. Barker and Foster, 1981), based on a dual porosity representation, represented fracture-matrix interactions as a diffusion process, but retained the assumption that fracture flow predominated. LOCAR research (Mathias et al., 2005; Mathias et al., in press) has developed a transient dual permeability unsaturated zone model, also with explicit representation of fracture-matrix diffusion, and with both fractures and matrix independently represented using Richards' equation. The modelling results, using Lambourn climate data for a hypothetical $10 \mathrm{~m}$ deep unsaturated zone underlying a shallow soil profile, indicate that the soil is an important buffer for high intensity rainfall. It also indicates that in the unsaturated Chalk below the soil, matrix flow is the predominant process (accounting for 70-90\% of recharge at the water table), with occasional episodic occurrence of fracture flow.

The LOCAR recharge sites provide a uniquelycomprehensive suite of instrumentation to monitor the Chalk unsaturated zone profile and water table response. However, the Chalk poses some difficult challenges for monitoring. Firstly, the depth of the unsaturated zone precludes monitoring of the complete profile; secondly, due to the fine pore sizes of the Chalk matrix, tensions of $30 \mathrm{~m} \mathrm{H}_{2} \mathrm{O}$ can be sustained before dewatering occurs, well beyond the observational range of conventional tensiometers; and thirdly, fracture flow is not directly observable. The LOCAR solution (Ireson et al., 2005; Ireson et al., in press) has been to use two complementary sets of methods to measure water potential and two to measure water content in the upper profile, with the additional measurement of deep groundwater response. The results from the West Ilsley site, on the Pang interfluve, show that the soil is indeed an important buffer of high intensity rainfall inputs (Fig. 11). Soil water potentials in the upper metre indicate that fracture flow is initiated, but the limited data currently available below $1 \mathrm{~m}$ suggest that propagation only occurs after significant water table rise. Equivalent data from a period of soil drying, with no possibility of fracture flow initiation, also shows a (small) water table rise. These results are therefore consistent with the hypothesis from the dual permeability model, namely that flow in the matrix predominates, with occasional fracture flow propagation.

These results have informed the development of an extension to the INCA model of nitrate in catchments (Whitehead et al., 1998 ; Wade et al., 2005 ), INCA-Chalk (Jackson et al., in press). For this, the unsaturated zone travel times are explicitly represented using the observed distribution of unsaturated zone depths (Fig. 10), associated unsaturated zone effective velocities for water and for solutes, and an additional parameter to represent the diffusion from matrix to fractures when the water table rises into the unsaturated zone.

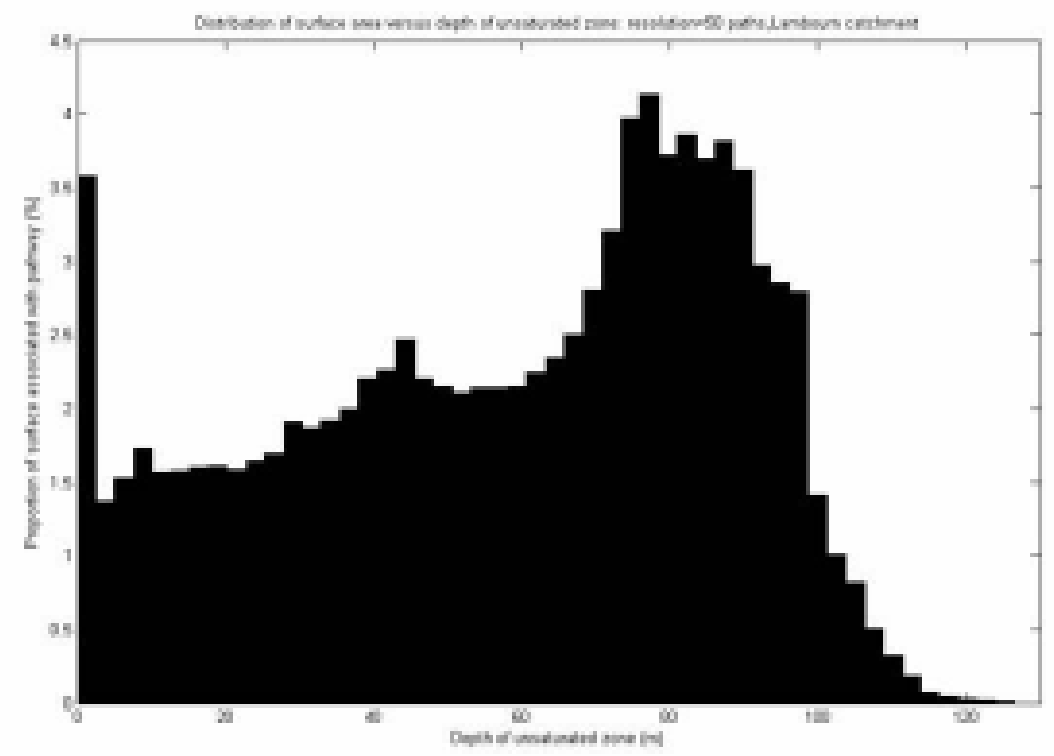

Fig. 10. Distribution of unsaturated zone depth, River Lambourn 
Some scientific and management implications

The results presented above have important implications for the scientific understanding of Chalk catchments and for their management:

1. Considering first the unsaturated zone, the results explain the duality of historical data concerning groundwater recharge and solute transport. The response times of the water table to surface precipitation are consistent with the movement of a pressure pulse down the unsaturated zone profile matrix. Slow migration of solutes is explained by rapid fracture-matrix interactions and predominantly matrix flow, consistent with the travel times of the order of 1 metre per year. Given the depths to water table illustrated in Fig. 10, it can be seen that there is a legacy of many decades of historical nutrient inputs in transit in the unsaturated zone, yet to reach the water table. This has profound implications, for the time-scales on which the effects of management controls, for example on surface nutrient applications, will have significant impacts on groundwater quality.

2. Turning to catchment modelling and analysis, the simple definition of a river catchment area is complex, and for the Pang at present unresolved. As illustrated in Fig. 5, groundwater catchment areas are different from topographic catchment areas, and vary seasonally. There is the added complication that for parts of the year, parts of the river are disconnected from the groundwater, which flows beneath the river to the Thames or Kennet. Any conventional surface water model will fail to represent rainfall-runoff response unless the catchment area is treated as unknown, and to the authors' knowledge, no surface water model is able to represent a time-variable catchment area.

3. Following on from the ambiguity in catchment areas, the tracing of pollutant pathways, for example from agricultural nutrient application to a particular receptor, is problematic. This would require detailed physicallybased groundwater modelling, but at a level of complexity that goes well beyond most current applications. An added complication is the presence of karst features, most notably the Blue Pool. The LOCAR project has developed working hypotheses to explain the duality of response, based on storage in the Palaeogene deposits, but the source area for this spring has yet to be defined with any reasonable degree of certainty.
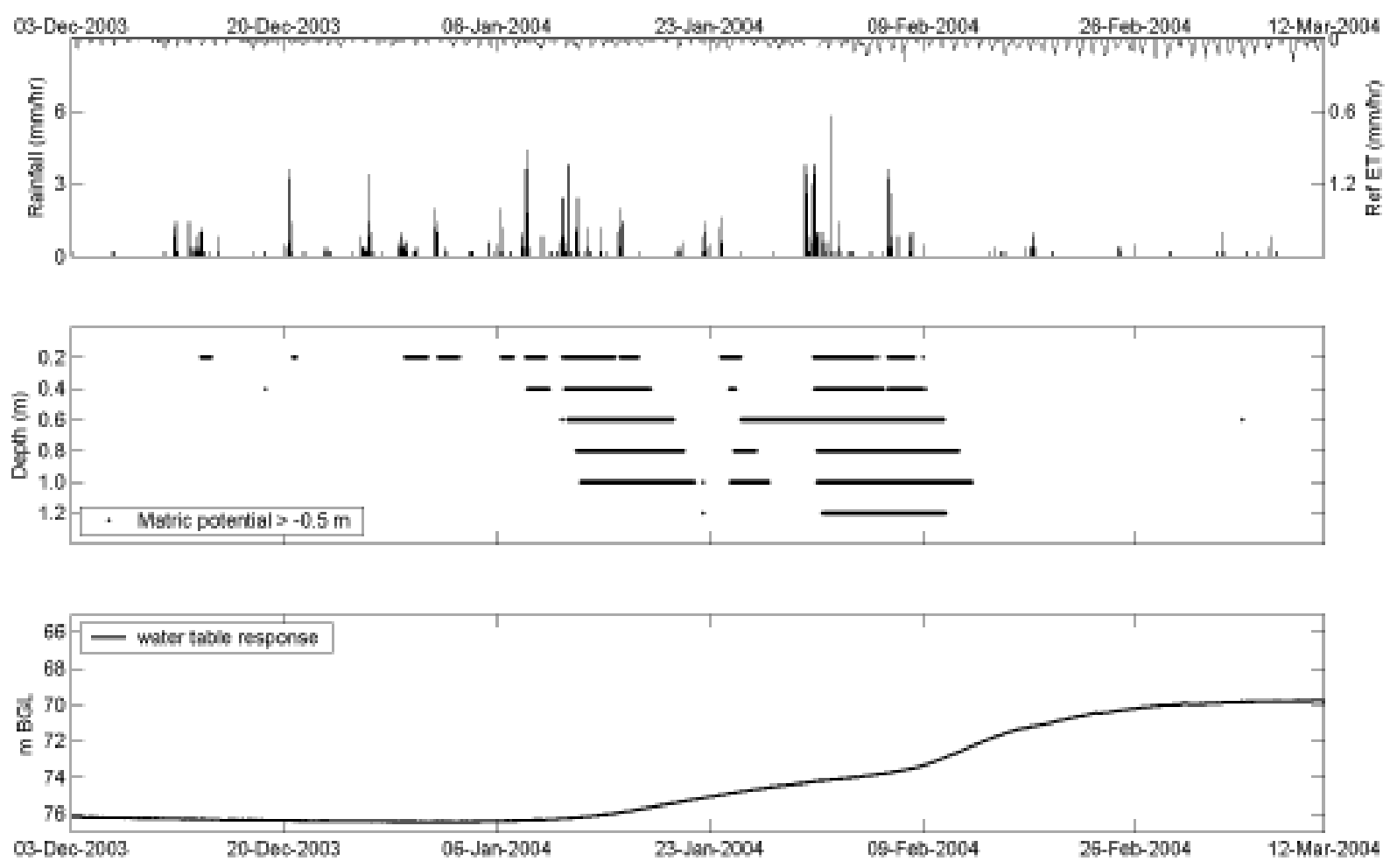

Fig. 11. Chalk unsaturated zone response, W. Ilsley - rainfall and potential evaporation, durations of potential fracture flow and water table response 
4. The Blue Pool is one aspect of the general issue of surface water-groundwater interactions. A naïve view of Chalk catchments is that the river is a simple drain for the groundwater system, expanding and contracting seasonally as groundwater tables rises and fall. Figure 8 shows a far more complex picture, with reaches of the river showing discrete inputs (from dry valleys and springs), gradual inflows and losing reaches, and the potential for characteristics to change seasonally. The analysis of the Westbrook Farm borehole arrays (Fig. 9) shows that at an intermediate location, different hydraulic heads arise in the Chalk, the overlying alluvial gravels and the river. Clearly, connectivity between these systems exists but is spatially highly heterogeneous, and the river alluvium is a significant element of the groundwater system, with the potential for collecting Chalk inflows and transmitting groundwater downstream, below the surface channel. The detail of these interactions is important for habitat protection (bearing in mind that a large number of Sites of Special Scientific Interest have been designated for Chalk riparian habitats), but their representation goes well beyond the resolution of current distributed groundwater models available for decision support.

\section{Conclusions}

The LOCAR research programme is multifaceted, and has been illustrated here simply with respect to subsurface flow and transport issues. Nevertheless, in considering these limited aspects of the programme, it can be seen that integrated monitoring has provided important insights into the complex functioning of groundwater-dominated catchments. Research into the ecological functioning of these systems is ongoing, and builds on the basic hydrological understanding reported above.

Some basic conclusions are:

- Hydrological science has some way to go before understanding these Chalk systems can be thought of as sufficient to manage water quality, wetlands and individual abstractions adequately, without significant risk of error.

- The management of riverine and riparian ecology requires a more detailed understanding of flow regimes than is currently available.

- At present, regional numerical models simulate very few of the mechanisms discussed. The development of appropriate models to represent this sort of complexity is needed to help understand, predict behaviour of and design monitoring for catchments under changing land use and climate.
- The continuation of LOCAR science is needed to allow validation and refinement of these conceptual models.

The results presented here thus raise important questions concerning the confidence that can be placed in models as routinely used for decision support and the level of knowledge required for catchment management to be placed on a secure scientific foundation. It is argued that major investment in integrated monitoring and modelling is essential to develop an adequate basis for management of the hydroecological functioning of catchment systems. LOCAR has been an important step forward for UK hydrological science, building on the legacy of Dr McCulloch, and a precursor, it is hoped, to further international initiatives in integrated catchments science, such as the US CUASHI programme.

\section{Acknowledgements}

The authors wish to acknowledge the contribution of data from Colin Neal (CEH), Paul Shand (BGS), John Bloomfield (BGS), Andrew Ireson (Imperial College) and Bethanna Jackson (Imperial College). Corinna Abesser (BGS) and Alex Gallagher (BGS) are thanked for field work and data collation. Financial support for the LOCAR Thematic Programme was provided by the Natural Environment Research Council (NERC). NERC funding is acknowledged by A.Binley through grant NER/T/S/2001/00948; H. Wheater and D. Peach through grant NER/T/S/2001/00942.

\section{References}

Adams, B., Peach, D. and Bloomfield, J.P., 2003. The LOCAR hydrogeological infrastructure for the Pang/Lambourn catchment. British Geological Survey Technical Report, CR/ $03 / 274 \mathrm{~N}$

Banks, D., Davies, C. et al., 1995. The Chalk as a karstic aquifer: evidence from a tracer test at Stanford Dingley, Berkshire, UK. Quart. J. Eng. Geol., 28 (Special), S31-S38.

CEC, 200.) Directive 2000/60/EC of the European Parliament and of the Council establishing a framework for the Community action in the field of water policy. CEC - Council of European Communities - CEC, L 327, P. 0001-0073.

http://europa.eu.int/comm/environment/water/waterframework/index en.html

Headworth, H.G., 1972. The analysis of natural groundwater fluctuations in the chalk of Hampshire. J. Inst. Water Eng., 26,107-124.

Ireson, A.M., Wheater, H.S., Butler, A.P., Finch, J., Cooper, J.D., Wyatt, R.G. and Hewitt, E.J., 2005. Field monitoring of matric potential and soil water content in the Chalk unsaturated zone. In: Advanced experimental unsaturated soil mechanics, Balkema, The Netherlands. 511-518.

Ireson, A.M., Wheater, H.S., Butler, A.P., Finch., J., Cooper., J. D., Mathias, S. A., 2006. Hydrological Processes in the Chalk unsaturated zone- insights from an intensive field monitoring programme, J. Hydrol. In press. 
Jackson, B.M., Wheater, H.S., McIntyre, N., Butler, A.P. and Mathias, S., 2006. A simple model of variable residence time flow and nutrient transport in the Chalk. J. Hydrol. In press.

Jones, H.K. and Robins, N.S., (Eds.), 1999. The Chalk aquifer of the South Downs. Hydrogeological report series of the British Geological Survey.

Leeks, G.J.L. and Jarvie, H.P., 1998. Introduction to the LandOcean Interaction Study (LOIS): rationale and international context. Sci. Tot. Environ., 210/211, 5-20.

Mathias, S.A., Butler, A.P., McIntyre, N., Wheater, H.S., 2005. The sigificance of flow in the matrix in the Chalk unsaturated zone. J. Hydrol., 310, 62-67.

Mathias, S., Butler, A.P., Jackson, B.M. and Wheater, H.S., 2006. Characterising flow in the Chalk unsaturated zone. J. Hydrol. In press.

Maurice, L.D., Atkinson, T.C., Barker, J.A., Bloomfield, J.P., Farrant, A.R. and Williams, A.T., 2006. Karstic behaviour of groundwater in the English Chalk. J. Hydrol. In press.

Mortimore, R.N., 1993. Chalk water and engineering geology, In: The hydrogeology of the Chalk of north-west Europe, R.A. Downing, M. Price and G.P. Jones (Eds.), Clarendon Press, Oxford, UK. 67-92.

Neal, C., (Ed.), 1997. The water quality of the Plynlimon catchments. Hydrol. Earth Syst. Sci., 3,1.

Neal, C., Skeffington, R., Neal, M., Wyatt, R. Wickham, H., Hill, L. and Hewitt, N., 2004a. Rainfall and runoff water quality of the Pang and Lambourn, tributaries of the River Thames, southeastern England. Hydrol. Earth Syst. Sci., 8, 601-613.

Neal, C., Jarvie, H.P., Wade, A.J., Neal, M., Wyatt, R., Turner, H., Hill, L. and Hewitt, N., 2004b. The water quality of the LOCAR Pang and Lambourn catchments. Hydrol. Earth Syst. Sci., 8, 614-635.

Oakes, D.B., 1977. The movement of water and solutes through the unsaturated zone of the Chalk of the United Kingdom,. Proc. 3rd Int. Hydrol. Symp., Colorado State Univ., Fort Collins, USA.

Peach, D.W., Adams, B., Hudson, J., Leeks, G. and Armitage, P., 2004. LOCAR/JIF Proposals for infrastructure and monitoring on the LOCAR Catchments. British Geological Survey Commissioned Report, CR/04/131N.
Peach, D., Shand, P., Gooddy, D., Abesser, C., Bloomfield, J.P. and Gallagher, A., 2006. The hydrogeology and hydrogeochemistry of the Pang and Lambourn catchments, Berkshire. British Geological Survey Commissionedl Report, CR/06/050N

Price, M., 1987. Fluid flow in the Chalk of England. Geol. Soc. Spec. Publ. 34, 141-156.

Price, M., Downing, R.A. and Edmunds, W.M., 1993. The Chalk as an aquifer. In: The hydrogeology of the Chalk of north-west Europe, R.A. Downing, M. Price and G.P. Jones (Eds.), Clarendon Press, Oxford, UK. 35-58.

Wade, A.J., Neal, C., Whitehead, P.G. and Flynn, N.J., 2005. Modelling nitrogen fluxes from the land to the coastal zone in European systems: a perspective from the INCA project. $J$. Hydrol., 304, 413-429.

Whitehead, P.G., Wilson, E.J. and Butterfield, D., 1998. A semidistributed Integrated Nitrogen model for multiple source assessment in Catchments (INCA): Part I - model structure and process equations. Sci. Tot. Environ., 210/211, 547-558.

Wheater, H.S. and O'Connell, P.E., 1998. National Infrastructure for Catchment Hydrology Experiments. Application for funding to 1998 Joint Infrastructure Fund (JIF), Imperial College London and University of Newcastle upon Tyne.

Wheater, H.S. and Peach, D., 2004. Developing inter-disciplinary science for integrated catchment management - the UK LOwland CAtchment Research (LOCAR) programme. Int. J. Water Resour. Devel., 20, 369-385.

Wheater, H.S., Butler, A.P., McIntyre, N., Whitehead, P.G., Johnes, P.J., Peach, D., Neal, C., Shand, P., Gooddy, D., Galagher, A., Jarvie, H.P., Kennedy, M., Wade, A.J., Lloyd, A., Franklin, P., Jackson, B.M., Mathias, S. and Ireson, A.M., 2006. Hydrogeochemical functioning of lowland permeable catchments: from process understanding to environmental management. Imperial College report to Environment Agency of England and Wales, February. 